\title{
A Sociolinguistic Study of English Taboo Language
}

\author{
Chunming Gao \\ School of Foreign Languages, Changchun University of Science and Technology, China
}

\begin{abstract}
In every society there are things which are believed to be not appropriate if spoken on public occasions. A large number of words are therefore taken as silly, vulgar or obscene when used in communication. These words are "taboos". This paper investigates all the major varieties of English taboo, i.e., bodily excretions, death and disease, sex, four-letter words, privacy and discriminatory language, which are respectively defined and provided with concrete examples. Euphemistic and roundabout ways of avoiding using taboo words are offered to deal with the situations.
\end{abstract}

Index Terms - sociolinguistic study, taboo, euphemism

\section{INTRODUCTION}

Taboo subjects include: body functions about sex and excretion, private parts of the body, illness and death; words believed to be blasphemy; income, salary, age of ladies, etc. Societies in different countries share this point of view, especially in English-speaking countries, but some of these are openly talked about in China.

Therefore, studies on English taboo have been an important topic under discussion in China among professionals. However, systematic and comprehensive studies on this especially in the fields of intercultural communication and sociolinguistics in China have not been easily seen yet. This paper is to explore various forms of English taboo, along which some comparisons between English and Chinese taboos are made, and euphemisms are thus introduced to relieve the harshness of taboo words. Through these, the socio-cultural values reflected by them are acquired.

\section{General Survey of Linguistic Taboo}

\section{A. Origin of Taboo Language}

Language is considered to contain special powers - be able to cure sickness, keep away evils, bring good to oneself and harm to an enemy. This belief that words control objects, people and spirits influences human activities through human history since ancient time. Such language usually has to be used with great care, and meticulous attention is paid to pronunciation and wording. People even tend to avoid mentioning them. When people have to talk about those things, they are talked about in very roundabout ways. Then we have instances of linguistic taboo and euphemism.

The word taboo is borrowed from Tongan, a language spoken by Polynesians in the Pacific archipelago, where any sacred or humble things are forbidden to touch or even to talk about. (Gu, 2002, p.264) "Taboo" does refer to this phenomenon, and means "holy" or "untouchable". For a long time, English and American believe that avoiding linguistic taboo is the symbol of their civilization. They refuse to talk about certain objects or actions and refuse to use the language referring to them.

\section{B. Definition of the Word "Taboo"}

According to Wardhaugh (2000, p.234), taboo is the prohibition or avoidance in any society of behavior believed to be harmful to its members in that it would cause them anxiety, embarrassment, or shame. Consequently, so far as language is concerned, certain things are not to be said or certain objects can be referred to only in certain circumstances, for example, only by certain people, or through deliberate circumlocution, i.e. euphemistically. ...Tabooed subjects can vary widely: sex, death, illness, excretion, bodily functions, religious matters, the supernatural. But quite often they extend to other aspects of social life.

The New Oxford Dictionary of English (2001) says, taboo (also tabu) is a social or religious custom prohibiting or restricting a particular practice or forbidding association with a particular person, place, or thing. Oxford Advanced Learner's English-Chinese Dictionary (Sixth edition) (2004) explains it like this, taboo is a cultural or religious custom that does not allow people to do, use or talk about a particular thing as people find it offensive or embarrassing; taboo words are words that many people consider offensive or shocking, for example because they refer to sex, the body or people's race. In Routledge Dictionary of Language and Linguistics (2000), taboo word is a term that is avoided for religious, political or sexual reasons and is usually replaced by a euphemism, e.g. rest room or bath room for toilet. In these dictionaries, the definitions of "taboo" seemingly vary but basically they are the same.

\section{Significance of Linguistic Taboo Study}


Most people who speak English know the rules of taboo and observe the rules. Breaking the rules may arouse considerable dissatisfaction. The use of a taboo word can lead to a variety of feedbacks, even physical violence or legal action.

When Shaw's use of bloody in Pygmalion or the use of damn in the movie Gone with the Wind a widespread public comment was aroused. The penalty for breaking a linguistic taboo can be severe, although perhaps not quite as much today as formerly, for obscenity is still a crime in many jurisdiction, but is hardly likely to cost you your life, as the violation of certain non-linguistic taboos, e.g., incest taboos, might be in certain places in the world. (Wardhaugh, 2000, p.234)

Peoples of different countries do not agree totally on what taboos are. Acts of human excretion and sexual intercourse are to be avoided in polite conversation. Age and salary should be avoided in English conversation. If they must be mentioned, they should be in a euphemistic way. In China, acts of human excretion and sexual intercourse are also taboo, but Chinese are more tolerant in talking about age and salary, which are often openly said even in serious public talk or conversation. Therefore it is important for a foreign language learner to acquaint himself with such knowledge.

\section{ENGLISH TABOO OF All VARIETIES}

\section{A. Bodily Excretions}

In any language there are certain things which must be avoided of mentioning. It applies to the words with such connotations as well. In English, the first of these that occur to people are words dealing with excretions. In fact, except tears, all the words concerning bodily excretions are believed taboo. The earliest sayings of "move the bowels" and "pass water" are considered inelegant. And "defecate" and "urinate" seem to be the words used in hospitals. Thus some euphemisms find themselves in replacing them, such as answer the call of a nature, do one's needs.

We ask where the "rest room" is, although we have no intention of having a rest. "Powder room" "loo", and "john" are other ways to say "toilet". Indeed, it is impossible to explain what a "rest room" is for without the use of roundabout ways or baby talk. It's "where you wash your hands" or "where you pee or poo", which are already euphemisms. Here we see a semantic change involved as the expressions used often have little to do with the referents.

\section{B. Death and Disease}

The fear of death carries into fear of words having to do with death and certain diseases. Many people believe words have great relations with what they symbolize, therefore "If anything should happen to me" means "when I die". Instead of saying "die", they use substitute expressions such as "pass away", "go to his reward", "answer the call of God", "go home", "to have a better place", "depart" and "go west". Similar words are so many, which is also the case in Chinese, like “走了”, “去了”, “去了极乐世界”, “去见阎王了”, “驾鹤西去”,

Some serious diseases are also taboo topics. Cancer is said in a roundabout way as "Big C" or "terminally ill". So is it with the disease of mental disorder and intelligence deficiency. Their euphemistic sayings may be "He is not all there." "She is a little eccentric / a little confused."

\section{C. $\operatorname{Sex}$}

According to Deng (1989, p.93), words having to do with anatomy and sex, and words even vaguely suggesting anatomical or sexual matters, have remarkable connotations, especially in American culture. Ladies of the nineteenth century could not bring themselves to say "breast" or "leg", not even of chicken, so that the terms "white meat" and "dark meat" were substituted. It was thought inelegant to speak of "going to bed", and "to retire" was used instead.

In the United States, the sexual revolution of the 1960s began to make it a great change. English-speaking countries tend to be freer and more tolerant on this in recent years. People, particularly younger ones, feel freer than they once did to take about sex-related subjects, masturbation, impotence, sexual activities of various kinds, and human sex organs are more likely to be talked or written about than they were 15 or 20 years ago. It is the same with China in present day. Thus to make love, to have sex with, etc., which are slightly "dressed-up" terms, are not all uncommon in writing now.

\section{Four-letter Words}

People are more tolerant with such words like fuck, tits, damn, the so-called "four-letter words". For instance, on the streets in London we could see the eye-catching shop name "FCUK", which in fact is the abbreviation of "French Connection United Kingdom". In spite of the sexual revolution, these words are still considered improper in most conversations, even in written form. In 1963, Eric Partridge included fuck in his Dictionary of Slang and Unconventional English. Despite his use of an asterisk for the vowel "u", the result was a storm of complaints to schools, libraries, and the police. Even today, the book is not always available on the open shelves of public libraries.

An even greater frenzy took place in 1959, when the unabridged edition of D. H. Lawrence's Lady Chatterley's Lover was published, which contained several instances of the word. The edition was banned because of obscenity, and court cases followed. Later, the word quickly appeared in the daily press, and it has become widespread in the literary works. Despite the development of liberal attitudes, there is still a strong antagonism to the use of four-letter words in public speech; and they are still not always to be found in dictionaries.

\section{E. Swear Words}


A remarkable variety of linguistic forms can be considered as cursing and swearing. There are the complex and sophisticated expressions that may be found in religious, legal, and other formal contexts. At the same time, there are many daily examples of taboo language that express such emotions as hatred, frustration and surprise. The most common speech comprise single words or short phrases, conveying different levels of intensity and attracting different degrees of social approval. English examples range from the mild such as heck and dash, to the most harsh one, fuck.

In these social contexts swearing can become a dominant linguistic feature, with sentences often containing taboo words. Sex, excretion, and supernatural power are the main sources of swear words. Half of them relate to words referring to body parts and functions that societies considered taboo, such as merd, ball, and other four-letter words. Another half deals with the names of gods, devils, etc. like God, Dear Lord, By the holy sacrament, Heavens, Hell...

\section{F. Privacy}

One of the reasons behind taboo on questions about personal matters is that English-speaking people put a high value on privacy. The English has a saying "A man's home is his castle", meaning a man's home is sacred to him; no one should come in without permission. So is it also with his life, personal affairs and private concerns. To ask questions concerning one's age, weight, income, marital status, politics, religion etc. would be considered prying into individual's personal life, which is another form of invading a person's "castle". (Deng, 1989, p.96)

"It's none of your business" may also reflect their value on privacy. Basically, you should not ask following questions to an English or an American. How old are you? What's your income? What's your religion? Are you married? Where are you going? How much did you pay for that?

Compared with English language, privacy does not sound familiar to Chinese people. Deng (1989, p.96) summarized two reasons. One is because of the close living arrangements of the Chinese. Villagers with scores or hundreds or more families densely packed in a small area have been typical of the Chinese countryside for centuries, which is quite different from the individual houses - often with a sizeable surrounding yard or garden for each — that have been characteristic of Western countries until comparatively recent times. Another reason may be the communal spirit or spirit of brotherhood that has long prevailed among the Chinese. Close contact and certain amount of mutual dependence and mutual concern mean that one person's affairs are also very much the affairs of one family, one's neighbors, and even the larger community that one belongs to.

\section{G. Discriminatory Language}

In recent times, many people have a growing tendency to be sensitive to what is called sexist language and racist language.

(1) Sexist language

Sexist language in its present day means language that is prejudiced against the female. Studies of sexism in the English language began by American women concerned with the effects of language on people's attitude towards women, which prejudice against women and in favor of men.

In speech and writing, for example, a person or a baby of unknown sex is referred to as he rather than she; the person (even a woman) presiding a meeting is the chairman. The history of our world is the history of mankind, not womankind. (Deng, 1989, p.98) Those words that are "unmarked" usually refer to the males. If referring to female, additional marks will be put before or after it, for example, waiter-waitress, hero-heroine, doctor-woman doctor.

There is a distinction between Mrs and Miss in both English and Chinese, which is not paralleled by a pair of titles showing whether or not a man is married. This implies unfairly that it is more important for a woman than for a man to show whether they are married, in spite of the introduction of Ms. In English, there is a tendency which involves words that are clearly restricted in one sex or the other, with female words tending to have less favorable meanings. A class pair is master and mistress, where the male meaning is "good", and the female meaning is "bad"; specifically, a mistress is a partner for extramarital sex. (Hudson, 2000, p.102) It reflects greater tolerance towards men in the sexual liberties.

(2) Racist language

Racism is the belief that some human races are inherently inferior to others. Racist language is that which shows a bias against certain racial or ethnic groups; it is the language that degrades or belittles them. (Deng, 1989, p.100)

In English language, much of the discrimination is against "black", whether black people or black color. The color white generally stands for innocence, purity, cleanliness, chastity-all words with positive, pleasant connotations. On the other hand, the color black is associated with wickedness, evil, filth; e.g., blackguard, blacklist, black mark. A member of a family that others are ashamed of is called a black sheep, not a white sheep. Even a lie, if it is a white lie, is not so bad as an ordinary lie, or black lie. However, it is not just blacks who are called degrading names in the U.S. There are names for other racial or ethnic groups as well: Italians are called dagos; Jews—kikes; Poles_polacks; Chinese-chinks; Japanese-japs; etc. All of these are insulting names, reflecting strong racial prejudice. (Deng, 1989, p.101)

Sometimes, one will hear racial remarks or "ethnic jokes" - jokes about the supposed stupidity or ignorance of certain groups. Such jokes may appear funny, but they are offensive nevertheless. In English, who are discriminated against most may be Dutch. In the seventeenth century, Britain often fought with the Netherlands, so the word "Dutch" has derogatory sense in many of its usage, e.g., double Dutch, to go Dutch, to talk Dutch, Dutch widow. Even swear words could not do without "Dutch", for example, "I'm a Dutch if ...". Same thing also occurs to French and people of other nations. We have following saying, to take French leave, Chinese copy, Spanish athlete, Irish bull, etc. 
Though the progress in some respects in the long river of history has been considerable, English still retains sexism and racism. You are never too careful to offend others without realizing it. What is more important is to keep up with the language and develop the sensitivity to the feelings of those who suffer from the prejudice. Understanding the social injustice is a guarantee against racist and sexist behavior.

\section{THE USE OF EUPHEMISMS}

In order to erase the harshness of taboo words, people have created euphemisms, words supplanted language considered too unpleasant. Robert Burchfield (1985), the editor of The Oxford English Dictionary, once observed that "a language without euphemisms would be a defective instrument of communication." So is taboo without euphemisms.

It appears that among all the people of the world there is a feeling that the names of the gods are too holy, and the names of evil spirits too terrifying, and they are not supposed to be treated as other common words. Therefore, they are purposefully avoided in a roundabout way. Gee, gosh almighty and gosh darn are ways to say Jesus, God Almighty and God damn. They are the use of euphemisms.

Euphemistic words and expressions allow us to talk about unpleasant things and neutralize the unpleasantness. They find dozens of expressions especially in the words of different jobs. Euphemisms make unpleasant jobs more attractive, even the word job itself is called profession. For example, janitor becomes custodian; sanitation engineer replaces garbage collector; gardener is changed into landscape architect.

Euphemistic terms are found used in every aspect of society, and one of them is the group of words describing "poor" or "poor condition". In English, except for poor, poverty stricken, be broke, there are in an awkward financial situation, badly off, etc. During the last twenty years or so, several other words have been trying to take their place, at least among educated circles. Wang (p.124) had a humorous sentence that “I used to think I was poor. Then they told me I wasn't poor, I was needy, I was deprived. Then they told me unprivileged was overused. I was disadvantaged. I still don't have a dime. But I have a great vocabulary."

Very often euphemisms can be used to avoid embarrassing situation and thus to protect individual's feelings. It becomes obvious in international relations. In 1983, after the U.S. sent its armed forces into Grenada, Regan showed his irritation with reporters at their "frequent use of the word invasion." "This", he said, "was a rescue mission". Grenada is a Third World country. Most such countries are poor. The terms for these countries are first underdeveloped nations; later developing nations and emerging nations took its place. The United Nations calls them less-developed countries. (Deng, p.89)

However, the excessive use of euphemisms is not appropriate either. Suppose an occasion where there is such a line "The departed rests in his casket in a slumber room where friends may visit with him before the grief therapist assists the dear one to his plot in a memoria garden". (Gu, p.274) Too many euphemisms in one sentence made it the opposite just to what is wished.

\section{CONCLUSION}

Taboo and euphemism affect us all. We all probably have a few things we refuse to talk about and still others we do not talk about directly. Even though we know the words, or else we express ourselves on them very indirectly. We may have some words which are hardly ever used because they are too emotional or offensive. Each social group is different from every other in how it behaves in this way or that way, and mutual respect in the use of language is the basis of friendly mutual communication. Perhaps one linguistic universal is that no social group uses language quite at random.

\section{REFERENCES}

[1] Burchfield, Robert. (1985). The English Language. Oxford: Oxford University Press.

[2] Crystal, David. (1997). The Cambridge Encyclopedia of Language (Second edition). Cambridge: Cambridge University Press.

[3] Deng, Yanchang \& Liu, Runqing. (1989). Language and Culture: A Comparison of English and Chinese Culture. Beijing: Foreign Language Teaching and Research Press.

[4] Gu, Jiazu \& Lu Sheng. (2002). Language and Culture. Shanghai: Shanghai Foreign Language Education Press.

[5] Hornby, A. S. (2004). Oxford Advanced Learner's English-Chinese Dictionary (Sixth edition). Oxford: Oxford University Press.

[6] Hudson, R. A. (2000). Sociolinguistics (Second edition). Beijing: Foreign Language Teaching and Research Press and Cambridge University Press.

[7] Pearsall, Judy. (2001). The New Oxford Dictionary of English. Oxford: Oxford University Press.

[8] Qi, Yucun. (2011). Modern Linguistics and Its Trend of Development. Shanghai: Shanghai Foreign Language Education Press.

[9] Roberts, William H. \& Turgeon, Gregoire. (2000). About Language: A Reader for Writers (Fifth edition). Boston: Houghton Mifflin Company.

[10] Russmann, Hadumod. (2000). Routledge Dictionary of Language and Linguistics. London: Routledge Press.

[11] Wang, Rongpei \& Wang Zhijiang. (2008). English Lexicology. Shanghai: Shanghai Foreign Language Education Press.

[12] Wardhaugh, Ronald. (2000). An Introduction to Sociolinguistics (Third edition). Oxford: Blackwell Publishers Ltd.

[13] Zhao, Yanping. (1999). Culture and Communication. Beijing: Renmin University of China Press. 
Chunming Gao was born in 1979 in Jilin Province, China. She received her M.A degree in Linguistics and Applied Linguistics in Foreign Languages from Changchun University of Science and Technology in 2006. She is currently a lecturer in its School of Foreign Languages. Her major research interests include applied linguistics and cross-cultural communication. 